\title{
Thermal decomposition of asbestos-containing materials
}

\author{
R. Kusiorowski $\cdot$ T. Zaremba $\cdot$ J. Piotrowski • \\ A. Gerle
}

Received: 13 October 2012/Accepted: 4 February 2013/Published online: 5 March 2013

(C) The Author(s) 2013. This article is published with open access at Springerlink.com

\begin{abstract}
Asbestos is the common name applied to a group of natural, fibrous silicate minerals, which were once one of the most popular raw materials to be used in building materials. Asbestos was mainly used for the production of assortment asbestos-cement products. Today it is generally known that asbestos belongs to the group of hazardous materials and shows carcinogenic activity. In Poland, asbestos-containing materials are stored in special landfills. This is not the final solution to the asbestos problem because the fibrous structure of asbestos is still maintained. Therefore, methods based on recycling must be found which will be able to destroy asbestos' dangerous fibrous structure. One of these methods may be thermal decomposition, where chemically combined water is released from the asbestos materials during heating. This leads to changes in the crystal structure and to the formation of new mineral phases. The aim of the preliminary research presented in this study was to determine the thermal behaviour as well as the structural and phase transformations of asbestos-cement materials during heating to high temperature. In the present study, three different types of asbestos-containing materials from Poland were examined. Differential thermal analysis, thermogravimetry with evolved gas analysis, X-ray diffraction, infrared spectroscopy and scanning electron microscopy were used
\end{abstract}

R. Kusiorowski $(\square) \cdot$ T. Zaremba $\cdot$ J. Piotrowski Department of Chemistry, Inorganic Technology and Fuels, Silesian University of Technology, B. Krzywoustego Str. 6, 44-100 Gliwice, Poland

e-mail: Robert.Kusiorowski@polsl.pl

A. Gerle

Institute of Ceramics and Building Materials, Refractory

Materials Division in Gliwice, Toszecka Str. 99,

44-100 Gliwice, Poland to study the thermal decomposition of asbestos-cement samples. It was found that there were no significant differences between the type of asbestos-cement samples used-their thermal decomposition takes place in a similar way.

Keywords Asbestos-cement - Thermal decomposition . DTA $\cdot$ TG-EGA $\cdot$ FT-IR $\cdot$ XRD $\cdot$ SEM

\section{Introduction}

Asbestos is the common name applied to a group of silicate minerals which have a fibrous crystal habit. There are six principal asbestos minerals-chrysotile, actinolite, tremolite, crocidolite (riebeckite), anthophyllite and amosite (grunerite) [1, 2]. A different chemical composition, structure and physical properties determined the use of these minerals in industry. In the past, asbestos minerals were used in about 3,000 different commercial products [3]. Chrysotile $\mathrm{Mg}_{3}(\mathrm{OH})_{4} \mathrm{Si}_{2} \mathrm{O}_{5}$ (white asbestos), crocidolite $\mathrm{Na}_{2} \mathrm{Fe}_{3}$ $\mathrm{Fe}_{2}\left[(\mathrm{OH}) \mathrm{Si}_{4} \mathrm{O}_{11}\right]_{2}$ (blue asbestos) and amosite $(\mathrm{Fe}, \mathrm{Mg})_{7}$ $\left[(\mathrm{OH}) \mathrm{Si}_{4} \mathrm{O}_{11}\right]_{2}$ (brown asbestos) had the largest industrial applications and were widely used in the past $[4,5]$.

Asbestos-cement products constituted the main assortment of products based on asbestos, and about $85 \%$ of mined asbestos was used for their production [1]. It was a very inexpensive and popular building material. Yet it is commonly known that asbestos minerals have carcinogenic properties [4] and that the risk of asbestos-related diseases is associated with inhalation of respirable asbestos fibres into the respiratory system [6]. In Poland, according to estimates, there are over 15 million tonnes of asbestos waste, of which over $90 \%$ comprises asbestos-cement wastes [7]. These wastes could be a source of secondary 
raw materials. The only requirement would be to destroy the fibrous structure of the asbestos. Currently, asbestos wastes are separated from the environment in landfills. This is not a final solution because the fibrous structure of asbestos has not completely been destroyed.

It is therefore advisable to attempt to dispose of asbestos minerals in asbestos-containing materials and to convert them into a harmless material. There are different ways of disposing of these wastes. Dissolution in acids or bases [8-12], hydrothermal [13] or mechanochemical treatment $[14,15]$ as well as fibre melting with further vitrification $[16,17]$ are methods that have been described in the technical literature. One of these methods could also be thermal treatment [18-21]. Asbestos minerals are naturally occurring hydrous silicates; thus they decompose to release chemically combined water by heating at high temperatures, which may lead to changes in the crystal structure and the formation of new phases without dangerous properties. The thermal decomposition of pure asbestos minerals is quite well known and has been described in specialist literature [22-32]. In the case of asbestos-cement samples, these investigations are not easy to carry out due to the complexity of the multiphase reacting system. The reaction paths should be completely modified due to the presence of Ca-rich cement phases and varying degrees of exposure to weather conditions.

Interesting information was provided by Dias et al. [33] in which the authors examined the influence of acid rains on the cementitious matrix of asbestos-cement slates. The authors stated that both old slate which had not been exposed to acid rain and non-aged asbestos-cement slate were similar, whereas slate exposed to an acidic attack was characterised by higher porosity, lower mechanical strength and a different mineral composition depending on the place of sampling. Calcite, chrysotile and vaterite were identified based on the XRD patterns of all of the tested samples. In the case of the non-aged samples of poorly crystallised calcite, anhydrous calcium silicate (alite and belite) and dolomite were also found. For samples exposed to acid rain, the mineral composition of the deteriorated layer and core were considered. The outer (deteriorated) layer presented only two crystalline minerals, such as calcite and chrysotile. The peaks of the CSH phase were presented for the core sample. In this sample's core, portlandite and ettringite were additionally identified. According to the authors, gypsum from the sulphate attack of the outer layer was dissolved by rainwater and infiltrated into the core of the sample. All samples were also examined by thermal analysis methods. The main compounds that decompose thermally up to $350{ }^{\circ} \mathrm{C}$ were the $\mathrm{CSH}$ phase, ettringite and gypsum. At around $450{ }^{\circ} \mathrm{C}$, the thermal decomposition of portlandite took place which was then followed by poorly crystallised calcite, dolomite and chrysotile in the range of
500-800 ${ }^{\circ} \mathrm{C}$. Well-crystallised calcite decomposed at a temperature above $800{ }^{\circ} \mathrm{C}[33]$.

In [34], the authors studied the thermal behaviour of two types of commercial asbestos-containing materials. In the first sample, the authors identified chrysotile asbestos, calcite and amorphous matter from the cementitious matrix. Thermal analysis mainly showed the presence of an endothermic peak at ca. $500-600{ }^{\circ} \mathrm{C}$ due to the dehydroxylation of the asbestos minerals (chrysotile). In a higher temperature range, there was also a minor endothermic peak that came from the thermal decomposition of calcite. As a result of this sample's calcination at $1,100{ }^{\circ} \mathrm{C}$ for $1 \mathrm{~h}$, the authors obtained a powder material in which diopside, gehlenite and Fe-forsterite were identified. The second tested sample is composed of a mixture of chrysotile and calcite as well as quartz, gypsum, muscovite, kaolinite, plagioclase and cristobalite. Thermal analysis of this material showed only an endothermic event at $T>700{ }^{\circ} \mathrm{C}$, mainly due to the decomposition of calcite. A complete transformation of asbestos also occurred after firing at $1,100{ }^{\circ} \mathrm{C}$ for $1 \mathrm{~h}$. The main mineral compounds were diopside, gehlenite, quartz and hematite [34].

The paper [35] presents the reactions and changes that take place during the calcination of asbestos-cement roofing slates to a complete transformation at $1,200{ }^{\circ} \mathrm{C}$. The mineralogical phase composition of asbestos-cement was varied and showed chrysotile, calcite, quartz and minor gypsum, illite, kaolinite and portlandite. The low content of the cement phases is explained by the carbonation process in air. The authors' study shows that the first phases which decomposed were gypsum (at about $350{ }^{\circ} \mathrm{C}$ ) and kaolinite $\left(400-600^{\circ} \mathrm{C}\right)$. Highly reactive metakaolinite was then available as a reactant for the next, high temperature crystallisation reactions. Chrysotile decomposed in the range of $700-800{ }^{\circ} \mathrm{C}$ with a prompt crystallisation to forsterite and enstatite. Calcite decomposed at about $900{ }^{\circ} \mathrm{C}$ and was accompanied by the decomposition of illite and anhydrite. The latter release groups that are useful for the creation of stable phase silicocarnotite. The large amount of $\mathrm{CaO}$ from the thermal decomposition of calcite reacts with silica and other components to form the typical clinker phases, such as larnite, ferrite and merwinite [35].

In turn, in [36] samples of commercial cement-asbestos slate were studied for which a qualitative analysis showed the calcite, CSH phase, chrysotile, larnite and amorphous phase as well as traces of quartz, hematite and dolomite. The sample was heated at a rate of about $20 \mathrm{~K} \mathrm{~min}^{-1}$. At $1,000{ }^{\circ} \mathrm{C}$, newly formed crystals appeared on the surface of the asbestos fibres. Qualitative analysis of the obtained powder material showed the presence of akermanite, merwinite, silicocarnotite and ferrite [36].

Paper [37] shows the experimental results of the thermal treatment of asbestos-cement. In contrast to the previously 
discussed products, this material contained amosite asbestos. The samples were thermally treated both under non-isothermal (a heating rate of $20 \mathrm{~K} \mathrm{~min}^{-1}$, a range from 20 to $1,200{ }^{\circ} \mathrm{C}$ ) and isothermal conditions (heated in a furnace between 400 and $1,100{ }^{\circ} \mathrm{C}, 2$-h temperature steps every $100{ }^{\circ} \mathrm{C}$ ). The asbestos-cement slate used was composed mainly of calcite and silica phases as well as amosite and micas or smectites as subordinate minerals. Thermal analysis of the tested asbestos-cement material showed a loss of absorbed water at temperatures lower than $250{ }^{\circ} \mathrm{C}$. In the next stage $\left(300-500{ }^{\circ} \mathrm{C}\right)$, the authors identified the combustion of organic material. After $500{ }^{\circ} \mathrm{C}$ and up to about $800{ }^{\circ} \mathrm{C}$, there was a significant loss of mass. The authors linked this with the loss of $\mathrm{CO}_{2}$ from the calcite breakdown. The last event to be observed in the thermal analysis was the removal of structural $\mathrm{OH}$ groups of amosite at $1,150{ }^{\circ} \mathrm{C}$. Amosite disappeared only at $900{ }^{\circ} \mathrm{C}$ by firing in the furnace. Besides the amosite, as a result of isothermal calcination at $900{ }^{\circ} \mathrm{C}$, both the calcite and silica phases also disappeared. The thermal decomposition of these compounds allowed for the crystallisation of larnite at $700{ }^{\circ} \mathrm{C}$ and wollastonite at $800{ }^{\circ} \mathrm{C}$. By increasing the temperature, development of the wollastonite phase increased. In each case in these articles, the obtained ground material after thermal treatment did not contain fibres. This powder material can be regarded as a potential secondary raw material in various industries, such as ceramics.

The aim of the research presented in this study was to determine the thermal behaviour as well as structural and phase transformations of different, national asbestos-cement materials during heating to high temperature.

\section{Experimental}

In the present study, three different types of asbestoscement materials were examined (Table 1). The specimens had been made in different factories and had been used in various applications. The specimens came from different regions of Poland and were exposed to external weather conditions in varying degrees. All slates were about 30-40 years old. The ACD and ACB slates were mounted on roofs directly after having been purchased and were continuously exposed to the outer atmosphere and weather conditions, whereas the ACZ slate sample was kept in a dry place and was not exposed to any direct interaction with the above-mentioned conditions. These asbestos materials were studied by differential thermal analysis (DTA) and thermogravimetric analysis with evolved gas analysis (TG-EGA). Their mineralogical composition and morphology were measured by X-ray diffraction (XRD), Fourier transform infrared spectroscopy (FT-IR) as well as scanning electron microscopy (SEM). The loss on ignition value (LOI) was also determined for all of the asbestos-cement samples. In this study, the LOI is the mass loss of a fully dried sample heated to a constant mass at $1,000{ }^{\circ} \mathrm{C}$ for $2 \mathrm{~h}$ and expressed as a mass percentage of the dried sample. The materials obtained after the loss on ignition test were examined by XRD, FT-IR and SEM.

Differential thermal analysis was performed using a Paulik-Paulik-Erdey type derivatograph (MOM, Hungary) within a range of temperature of $20-1,000{ }^{\circ} \mathrm{C}$. The conditions were: mass of sample $500 \mathrm{mg}$, air atmosphere, heating rate $10 \mathrm{~K} \mathrm{~min}^{-1}$, and alumina crucible and $\mathrm{Al}_{2} \mathrm{O}_{3}$ as the reference material. High-temperature thermogravimetric (TG) analysis connected with evolved gas analysis (EGA) were performed using the thermal analyser STA 409 PC NETZSCH which was coupled with the quadrupole mass spectrometer QMS 403 C Aëolos. A total of $32 \mathrm{mg}$ of sample was placed in an alumina crucible. The heating rate of the sample was $5 \mathrm{~K} \mathrm{~min}^{-1}$. Testing was performed in air with a flow rate of $30 \mathrm{~mL} \mathrm{~min}{ }^{-1}$. XRD analysis of the samples was carried out using a Seifert XRD-3003 TT diffractometer (CuK $\alpha$ radiation, Ni filter, $40 \mathrm{kV}, 40 \mathrm{~mA})$. The microstructure of the samples was evaluated by SEM (Tesla BS 340, Czech Republic). Observations were made after coating the surface of the samples with a thin layer of gold. IR spectra were measured on a Nicolett 6700 FT-IR spectrophotometer (ATR method).

\section{Results and discussion}

The values of loss on ignition (Table 1) for the investigated asbestos-cement samples were varied. The lowest value of LOI ( $\sim 22 \%$ ) was observed for the ACZ sample. This may confirm the origin of this asbestos-cement sample and the conditions under which it was kept. Higher values of mass loss after ignition were obtained for asbestos-cement samples which had been exposed to external weather conditions, $\sim 23$ and $26 \%$, respectively for the ACD and ACB samples. The higher value for the ACB sample may have been due to the location from which this sample came. In contrast to the ACD and ACZ samples, which came from a recreational area of the Beskid Zywiecki mountains, the ACB sample is from the Upper Silesian industrial region. In this case, the ACB sample was probably more easily exposed to long-term ageing by carbonation, leaching and acid rain.

Diffraction bands from the cementitious matrix are dominant on the XRD patterns of all the samples (Fig. 1). The main crystal components were portlandite $\mathrm{Ca}(\mathrm{OH})_{2}$ and/or calcite $\mathrm{CaCO}_{3}$. These samples also had a varied asbestos mineral type. The ACD and ACZ samples had only green-yellowish fibres, while the ACB sample also 
Table 1 Characteristics of the tested samples

\begin{tabular}{llll}
\hline Symbol & Origin and description & Included asbestos minerals & LOI/mass\% \\
\hline ACZ & $\begin{array}{l}\text { Around the city of Żywiec, Beskid Mountains, pressed flat sheet, } \\
\text { not exposed to outside weather conditions }\end{array}$ & Chrysotile \\
& $\begin{array}{l}\text { Around the city of Żywiec, Beskid Mountains, pressed flat sheet, } \\
\text { exposed to outside weather conditions }\end{array}$ & Chrysotile \\
ACD & $\begin{array}{l}\text { Around the city of Mikołów-Bujaków, Upper Silesia, corrugated sheet, } \\
\text { exposed to outside weather conditions }\end{array}$ & Chrysotile, crocidolite \\
ACB & & & 23.3 \\
&
\end{tabular}

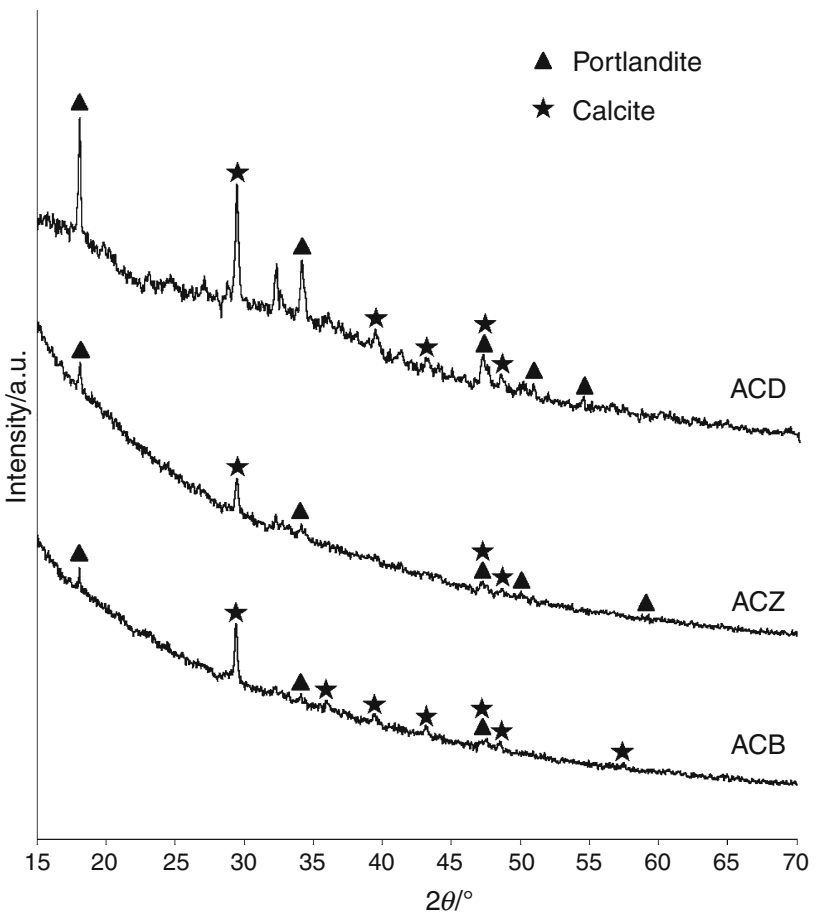

Fig. 1 XRD patterns of tested asbestos-cement samples

had dark blue fibres. The XRD patterns of the separated fibres showed the presence of chrysotile asbestos in the ACZ and ACD samples, while the ACB sample had chrysotile and crocidolite (Fig. 2). The SEM images of both the asbestos-cement slates used and the separated asbestos fibres are shown in Figs. 3 and 4. The surface of the asbestos-cement slate is smooth and compact, and bundles of the asbestos fibres are well-embedded in the cement mass. In the fracture of the sample, the asbestos fibres can clearly be seen. Their structure remains undestroyed even after milling. The appearance of the separated asbestos fibres is also different. The chrysotile fibres are more flexible, while the crocidolite has more rigid fibres which look like needles. There are also visible growths on the fibres which come from the cementitious matrix.

Thermal decomposition of the tested asbestos-cement samples is similar (Figs. 5, 6). Effects which came from the decomposition of the cementitious matrix dominated in all

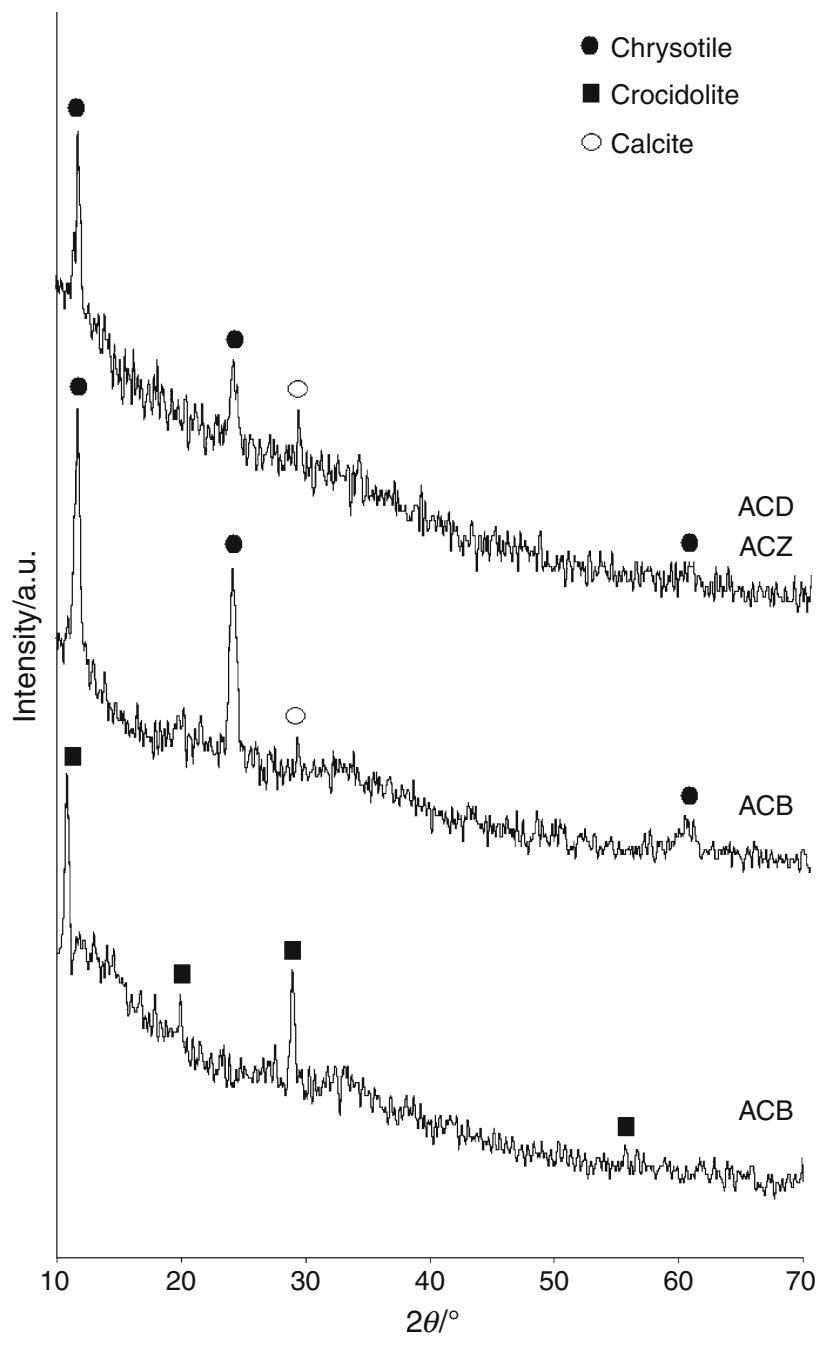

Fig. 2 XRD patterns of separated asbestos fibers from asbestoscement slates

of the DTA curves obtained (Fig. 5). The thermal reactions were generally endothermic. Due to the small amount of asbestos in the asbestos-cement material, there were no visible characteristic effects from the decomposition of the asbestos minerals. In the temperature range of $100-250{ }^{\circ} \mathrm{C}$, wide endothermic peaks were visible on all of the DTA curves. For all of the samples, this was a water loss from the $\mathrm{CSH}$ phase $[38,39]$. Endothermic peaks at $\sim 520{ }^{\circ} \mathrm{C}$ 

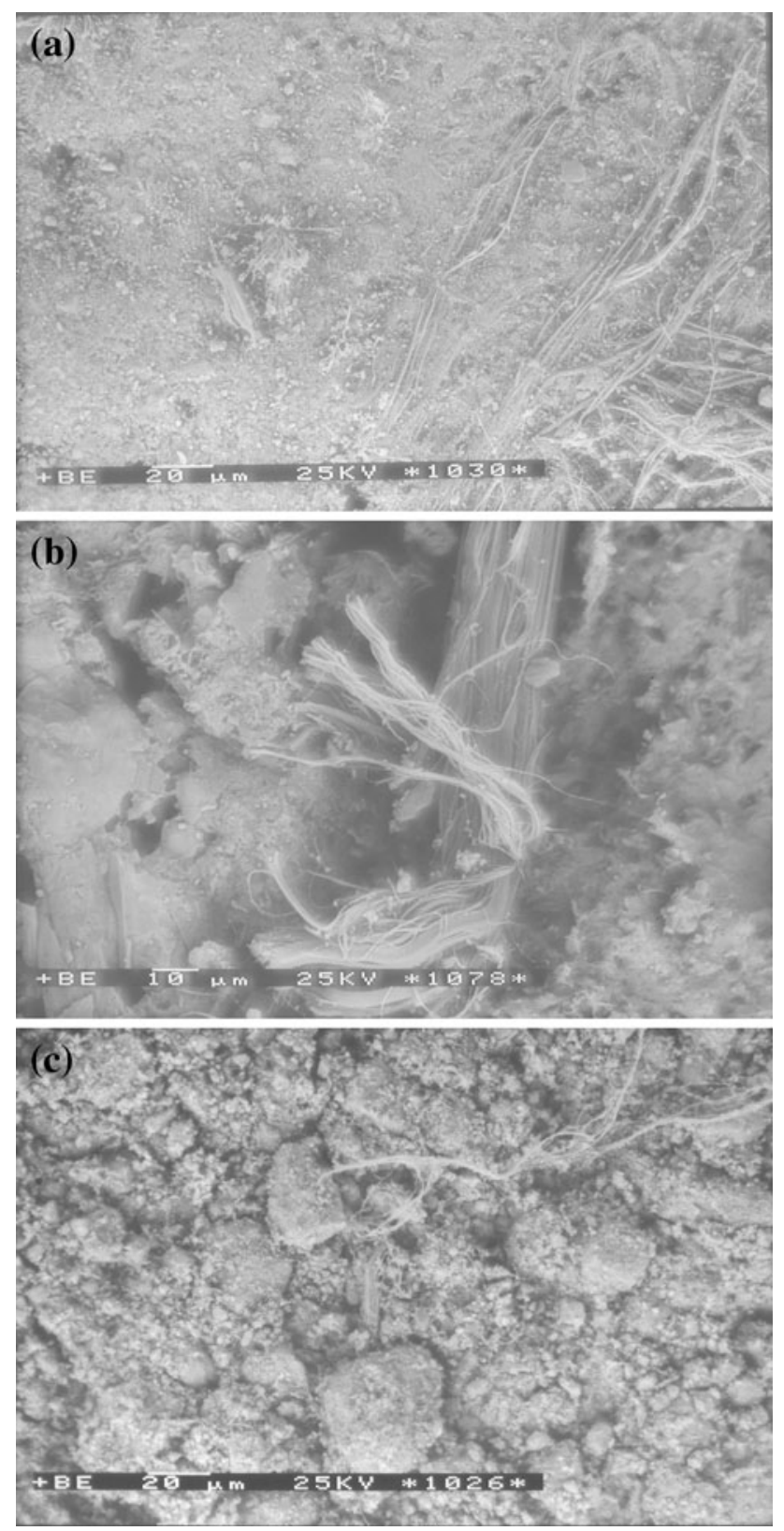

Fig. 3 SEM images of selected used asbestos-cement samples: a surface, $\mathbf{b}$ fracture, $\mathbf{c}$ after milling

for the samples indicated the presence of portlandite $\left(\mathrm{Ca}(\mathrm{OH})_{2}\right)$, which was one of the abundant phases in the hydrated cement pastes $[39,40]$. The weakest effect connected with the dehydroxylation of portlandite $\left(\mathrm{Ca}(\mathrm{OH})_{2} \rightarrow\right.$ $\mathrm{CaO}+\mathrm{H}_{2} \mathrm{O}$ ) was observed in the ACB sample. This may indirectly confirm this sample's higher carbonation degree. Weak endothermic effects were observed in the temperature range of $650-800{ }^{\circ} \mathrm{C}$ for all of the tested samples. The wide temperature range of these effects may indicate a different degree of crystallinity of calcite, the presence of other carbonate minerals [33] or the thermal decomposition of other cementitious phases. Stepkowska et al. [41] stated that the
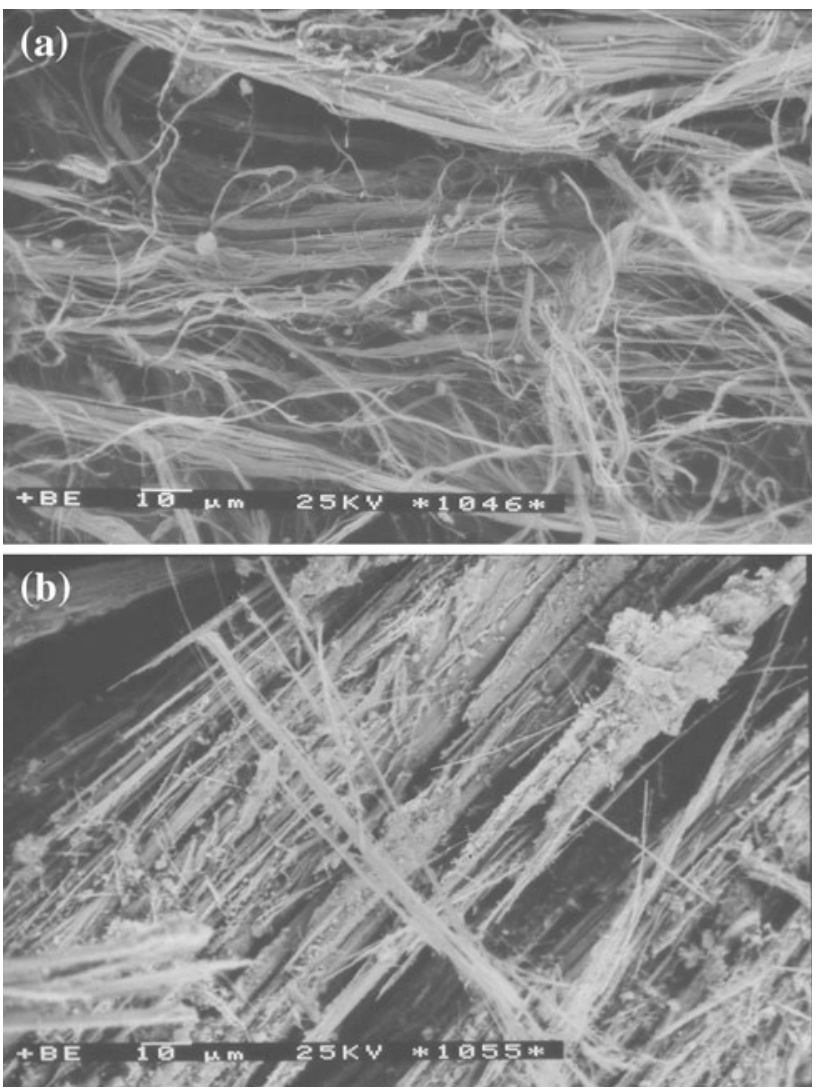

Fig. 4 SEM images of asbestos fibres separated from cementitious matrix: a chrysotile, $\mathbf{b}$ crocidolite

rest of the sorbed water escaped from aged cement pastes between 500 and $700{ }^{\circ} \mathrm{C}$, possibly upon dehydroxylation of the jennite-like compound $\left(9 \mathrm{CaO} \cdot 6 \mathrm{SiO}_{2} \cdot 11 \mathrm{H}_{2} \mathrm{O}\right)$. At a higher temperature (in the range of $800-900{ }^{\circ} \mathrm{C}$ ), the decomposition of carbonates takes place, especially of calcite $\left(\mathrm{CaCO}_{3}\right)$ [42]. Calcite was formed as a result of the long-term ageing of the cement-asbestos samples. It was possibly formed not only on portlandite carbonation, but also from other compounds, such as amorphous carbonate or CSH gel [41]. For the ACB sample, the thermal effect associated with calcite decomposition was the strongest. This is in accordance with an earlier statement on the higher carbonation degree of the sample from Upper Silesia.

Additional information on the thermal decomposition of asbestos-cement samples was provided by carrying out high-temperature TG/DTG measurements in connection with EGA (Fig. 6). In the temperature range of $100-200{ }^{\circ} \mathrm{C}$, mass loss ( 5-6 mass \%, based on TG) is visible on the thermogravimetric curves. On the EGA curves of all the tested samples, a peak which came from the released water vapour is clearly visible in this range. This is adsorbed water and water from the thermal decomposition of the hydrates $\mathrm{CSH}$ phase [41]. Next, in the temperature range of $200-400{ }^{\circ} \mathrm{C}$, small mass loss ( 2 mass $\%$ ), which may 


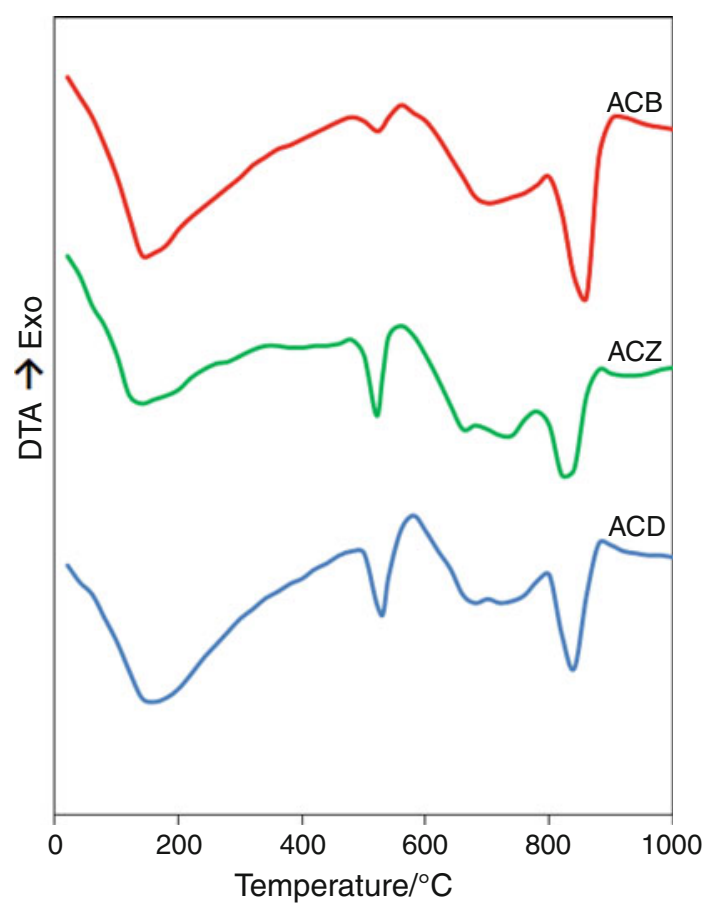

Fig. 5 DTA curves of tested asbestos-cement samples

have come from combustion of organic material traces [37], was observed for all of the samples. These traces can be formed as a result of long-term contact with the external environment. A mass change at $\sim 430{ }^{\circ} \mathrm{C}(\sim 2$ mass $\%$ for the ACZ and ACD samples, a trace for the ACB sample) for all of the samples indicates the presence of portlandite $\left(\mathrm{Ca}(\mathrm{OH})_{2}\right)$ [39, 40]. This is one of the main minerals in cement paste. EGA mainly showed the presence of water. Due to the much smaller amount of samples in this measurement as compared to the DTA analysis (32 vs. $500 \mathrm{mg}$ ), the temperature of the maximum peak is shifted towards lower values of temperature. At a higher temperature (in the range of $500-750{ }^{\circ} \mathrm{C}$ ), decomposition of carbonates, especially calcite $\left(\mathrm{CaCO}_{3}\right)$ [41], takes place. This is indicated by a clearly visible loss of mass. For the ACZ and ACD samples, the mass change is 10-12 mass\%, while for the ACB sample, it is more than 16 mass\%. EGA clearly showed the presence of carbon dioxide in the flue gas. A wide temperature range of $\mathrm{CO}_{2}$ release may indicate a different degree of crystallinity of the calcite or the presence of other carbonate minerals in the tested samples [33]. The weak effect from $\mathrm{H}_{2} \mathrm{O}$ at $600{ }^{\circ} \mathrm{C}$ on the EGA curve may come from the thermal decomposition of chrysotile asbestos and/or more complicated CSH phase components $[41,43]$.

In the temperature range of $1,250-1,350{ }^{\circ} \mathrm{C}$, mass losses ( $\sim 2$ mass\%) are visible on the TG curves of all the tested asbestos-cement samples. Analysis of evolved gas confirmed the presence of sulphur as $\mathrm{SO}_{2}$ in all of the tested samples. Sulphur is present in the investigated materials because gypsum $\left(\mathrm{CaSO}_{4} \cdot 2 \mathrm{H}_{2} \mathrm{O}\right)$ was added as the settingtime regulator for cement. Gypsum can also be formed as a result of the long-term effects of the atmosphere and acid rain [33]. The course of the DTG curves demonstrates that the thermal decomposition of the samples in the temperature range between 1,250 and $1,350{ }^{\circ} \mathrm{C}$ took place in several stages. This effect is probably related to the decomposition of anhydrite $\left(\mathrm{CaSO}_{4}\right)$. The temperature at which calcium sulphate itself starts to decompose is controversial. The decomposition of anhydrite occurs in a temperature range of $1,000-1,100{ }^{\circ} \mathrm{C}$ according to the possible reactions (1-3) $[44,45]$ :

$\mathrm{CaSO}_{4} \rightarrow \mathrm{CaO}+\mathrm{SO}_{3}$

$2 \mathrm{CaSO}_{4} \rightarrow 2 \mathrm{CaO}+2 \mathrm{SO}_{2}+\mathrm{O}_{2}$

and then in the presence of oxygen (e.g. atmospheric):

$\mathrm{SO}_{2}+1 / 2 \mathrm{O}_{2} \rightarrow \mathrm{SO}_{3}$

According to [46], the thermal decomposition of pure $\mathrm{CaSO}_{4}$ occurred at about $1,240{ }^{\circ} \mathrm{C}$ and was practically complete by $1,450{ }^{\circ} \mathrm{C}$. This temperature gives rise to the formation of calcium oxide and sulphur anhydrides according to the reactions $(4,5)[46]$ :

$\mathrm{CaSO}_{4} \rightarrow \mathrm{CaO}+\mathrm{SO}_{3}$

$\mathrm{SO}_{3} \rightarrow \mathrm{SO}_{2}+1 / 2 \mathrm{O}_{2}$

On the other hand, in a reductive atmosphere, anhydrite decomposition probably takes place according to the following reactions $(6,7)$ [47]:

$\mathrm{CaSO}_{4} \rightarrow \mathrm{CaO}+\mathrm{SO}_{3}$
$\mathrm{CaSO}_{4}+4 \mathrm{CO} \rightarrow \mathrm{CaS}+4 \mathrm{CO}_{2}$

If other compounds were present in the reaction system, such as $\mathrm{SiO}_{2}$, the thermal decomposition of anhydrite began at about $900{ }^{\circ} \mathrm{C}$ and led to the formation of $\mathrm{CaSiO}_{3}$ as the major product and $\mathrm{Ca}_{2} \mathrm{SiO}_{4}$ as the minor product below $1,250{ }^{\circ} \mathrm{C}$. The reaction (8) is [48]:

$\mathrm{CaSO}_{4}+\mathrm{SiO}_{2} \rightarrow \mathrm{CaSiO}_{3}+\mathrm{SO}_{2}+1 / 2 \mathrm{O}_{2}$

The decomposition of anhydrite occurred in the presence of other phases which came from the multiphase system of asbestos-cement. An interpretation of the changes in the high-temperature range requires a more in-depth investigation.

Thermal behaviour of the tested asbestos-cement samples was confirmed by infrared spectra. Figure 7 shows the results of the FT-IR investigation as carried out on the asbestos-cement samples received and on the powders obtained after the LOI test, respectively. These curves are marked as SP. For all of the tested samples of raw asbestos-cement, two IR absorbance bands related to the $\mathrm{OH}$ stretch are well visible in the high wavenumbers region, i.e. 
Fig. 6 High-temperature TG/DTG curves and evolved gas analysis of tested samples: a ACZ, b ACD, c ACB (a) TG $/ \%$

$\mathrm{DTG} /(\% / \mathrm{min})$

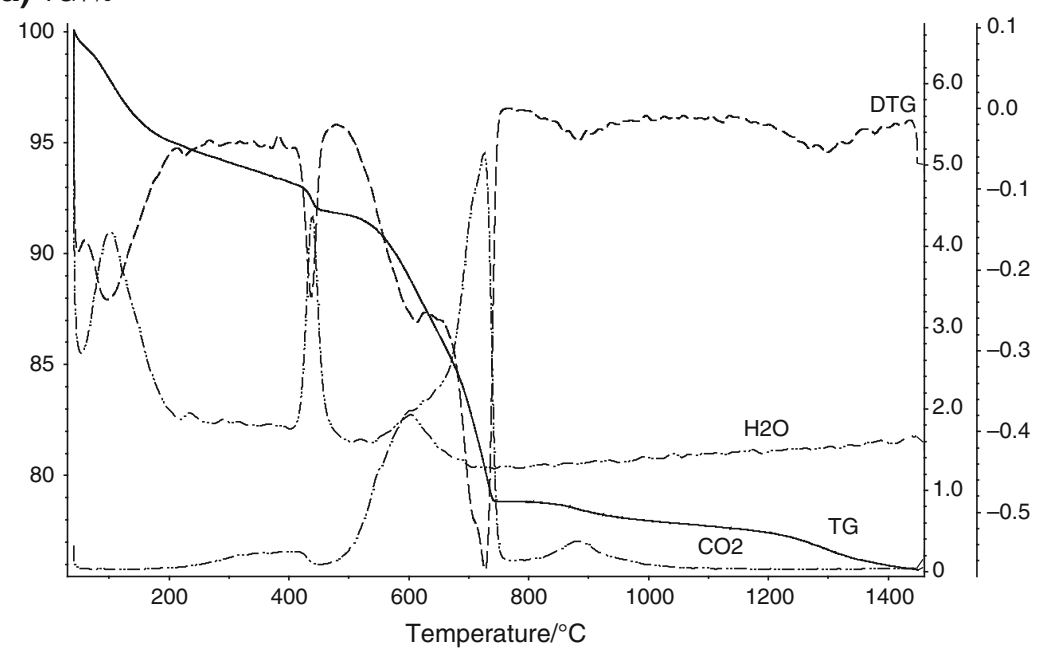

(b) TG $/ \%$

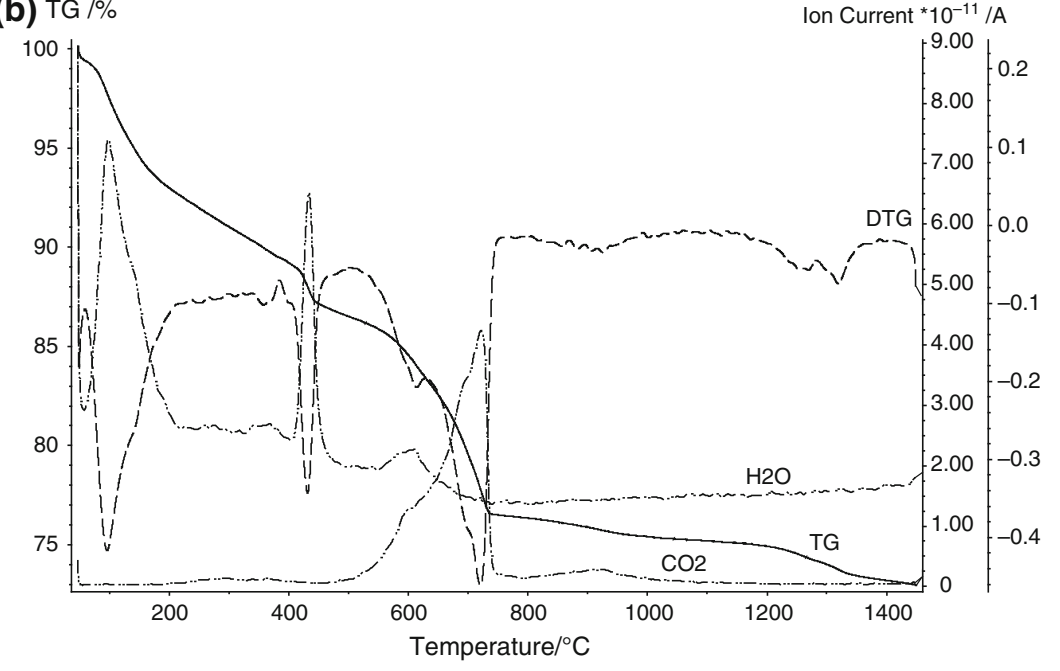

(c) TG $/ \%$

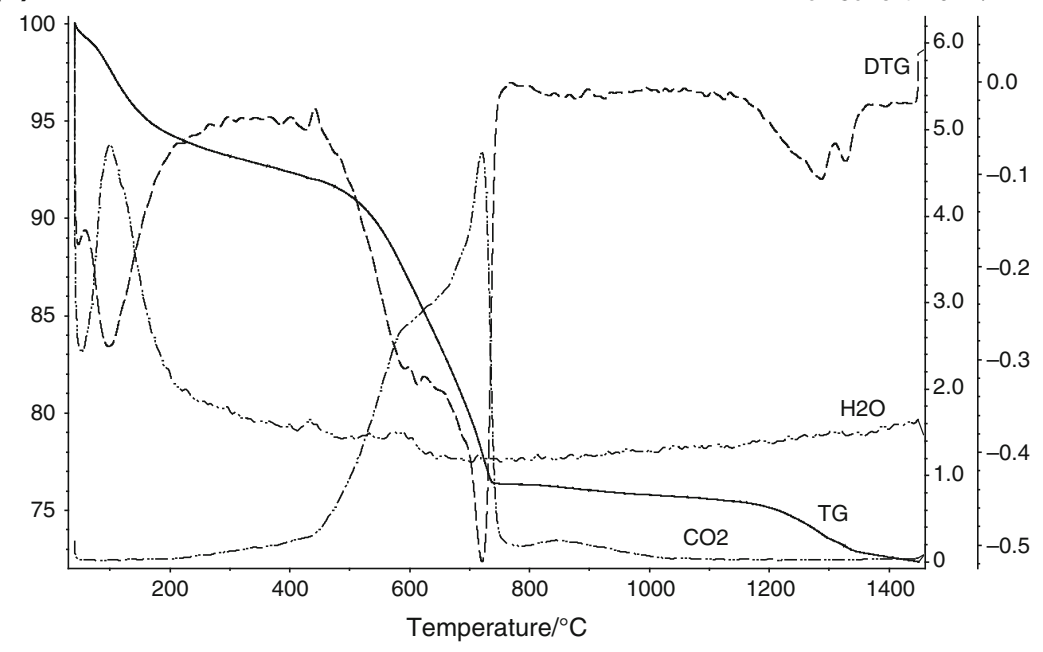


$3,600-3,800 \mathrm{~cm}^{-1}$. The characteristic double peak came from the $\mathrm{OH}$-stretching vibrations of asbestos and from the portlandite contained in the cementitious matrix. The absorption bands centred at about 1,420 and $880 \mathrm{~cm}^{-1}$ were due to the $v_{3}$ and $v_{2}$ modes of $\mathrm{CO}_{3}^{-2}$, while those centred at about $1,000 \mathrm{~cm}^{-1}$ came from $\mathrm{SiO}_{4}^{-4}$ [15]. The weak absorption bands at $1,100 \mathrm{~cm}^{-1}$, which are visible as an inflection point, correspond to the modes of $\mathrm{SO}_{4}^{-2}$. The presence of carbonates, silicates and sulphates is evident due to the nature of asbestos-cement, which contains set cement.

Thermal decomposition of the asbestos-cement samples was confirmed by infrared spectra obtained for the material after the loss on ignition test. The characteristic double peak at $3,640-3,680 \mathrm{~cm}^{-1}$ corresponding to the $\mathrm{OH}$ stretching vibrations of asbestos (and also from portlandite) disappeared. This confirmed the thermal decomposition of the asbestos minerals. A characteristic carbonate band at $\sim 1,400 \mathrm{~cm}^{-1}$ also disappeared. Heating the samples caused other appreciable changes in their FT-IR spectra,

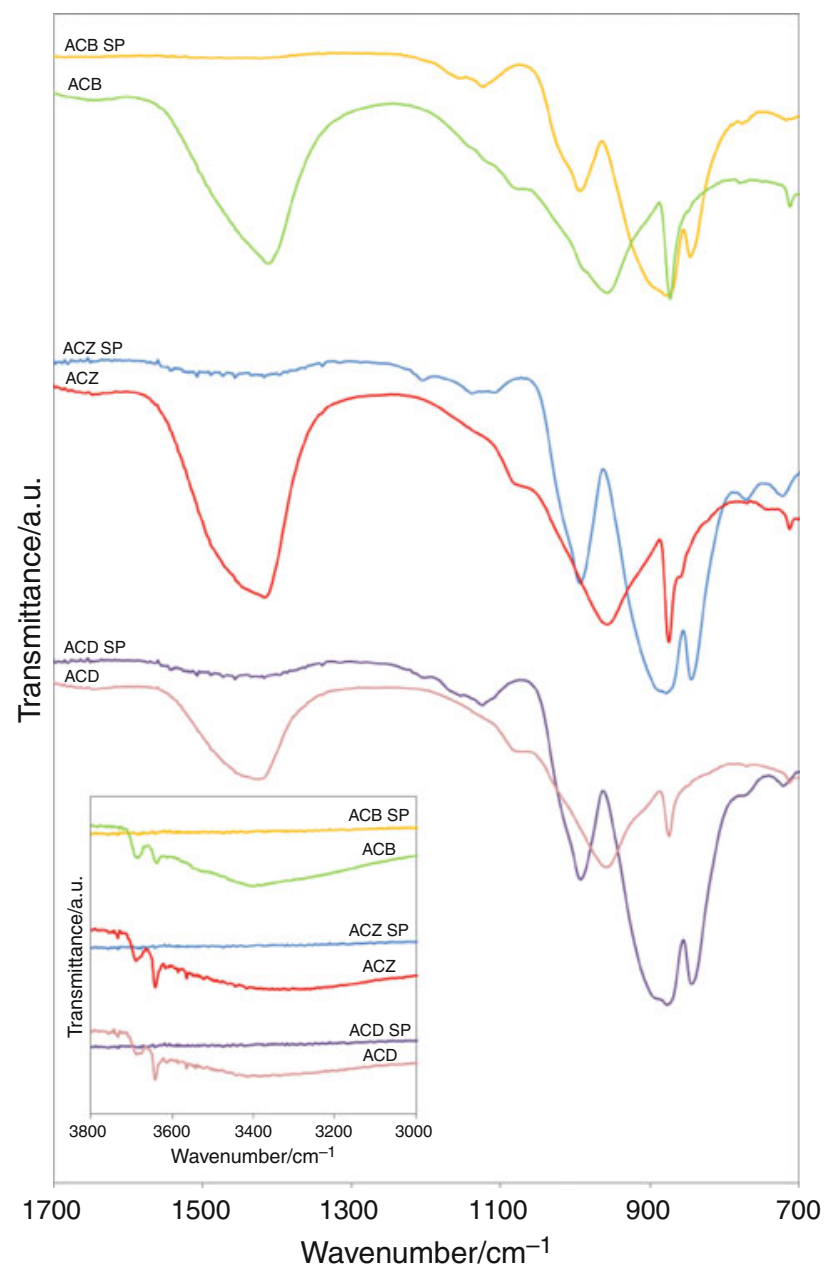

Fig. 7 FT-IR spectra of tested asbestos-containing materials before and after LOI test (marked as SP)

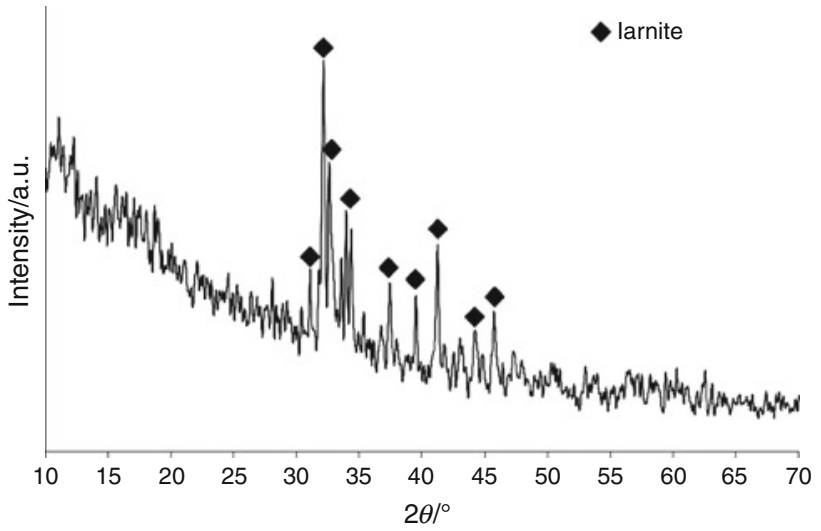

Fig. 8 XRD pattern of ACB asbestos-cement sample after LOI test

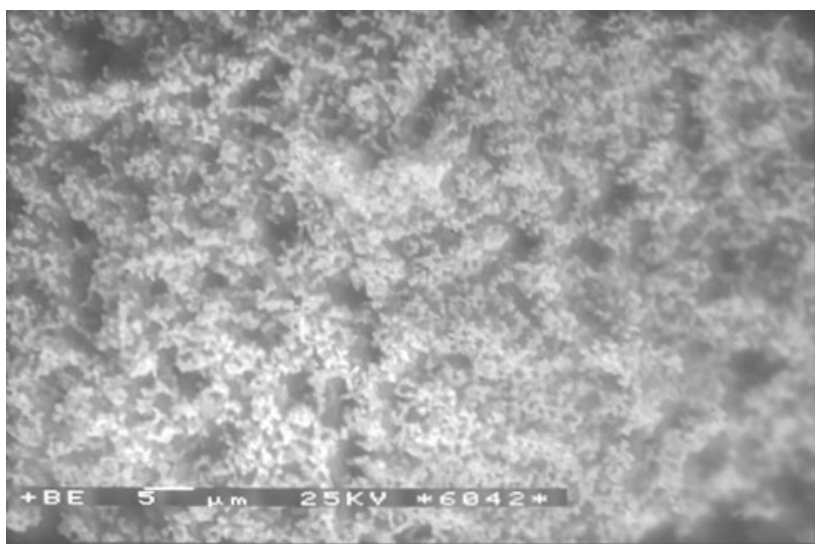

Fig. 9 SEM image of material obtained after LOI test and soft crush in a mortar

which confirms that they undergo structural transformations under heating. The characteristic triplet within $880-1,100 \mathrm{~cm}^{-1}$ is clearly shifted towards the lower frequencies. The IR bands recorded in the region of $\sim 980-870 \mathrm{~cm}^{-1}$ and at $\sim 845 \mathrm{~cm}^{-1}$ are typical of the larnite crystal [49].

The thermal decomposition of the asbestos-cement samples was additionally confirmed by XRD analysis. New peaks can be seen on the XRD pattern (Fig. 8) of one selected sample after thermal analysis. These indicate the formation of larnite $\left(\mathrm{Ca}_{2} \mathrm{SiO}_{4}\right)$. Larnite was also identified in the other investigated asbestos-cement samples. Asbestoscement materials, after thermal treatment and loss of chemically bonded water, show high grinding ability. The SEM image of material obtained after both loss on ignition analysis and being crushed in a hand mortar is presented in Fig. 9. Powder material was obtained even after a soft and hand crush in an agate mortar, where fibrous morphology is not retained. 


\section{Conclusions}

This preliminary study leads to the conclusion that material obtained through the thermal treatment of asbestos-cement waste is asbestos-free and can be favourably recycled in the future in the field of ceramics or building materials. As a result of this process, the fibrous structure of asbestos minerals is changed and the obtained materials have high grinding ability. It can particularly be concluded that:

(1) Calcination of asbestos-cement wastes at $\sim 1,000{ }^{\circ} \mathrm{C}$ is sufficient to totally destroy the dangerous structure of asbestos. In fact, the typical asbestos XRD peaks, spectroscopy infrared bands and fibrous phase completely disappear after this treatment.

(2) There are no significant differences in thermal decomposition to a temperature of $1,000{ }^{\circ} \mathrm{C}$ between the types of asbestos-cement samples used. In each case, thermal decomposition takes place in a similar way. This can be an important advantage with respect to asbestos-cement wastes due to the possible utilisation and recycling of these wastes.

Acknowledgements The authors gratefully acknowledge anonymous reviewers for their careful revision of the manuscript. The main author was a scholarship student in the Project "SWIFT (Scholarships Supporting Innovative Technology Forum)" POKL.08.02.01-24-005/ 10 co-financed by the European Union under the European Social Fund.

Open Access This article is distributed under the terms of the Creative Commons Attribution License which permits any use, distribution, and reproduction in any medium, provided the original author(s) and the source are credited.

\section{References}

1. Virta RL. Mineral commodity profiles-asbestos. US Geol Surv Circ. 2005;56p:1255-KK.

2. Sporn TA. Mineralogy of asbestos. In: Tannapfel A, editor. Malignant mesothelioma. Berlin: Springer; 2011. p. 1-11.

3. Harris LV, Kahwa IA. Asbestos: old foe in 21 st century developing countries. Sci Total Environ. 2003;307:1-9.

4. LaDou J, Castleman B, Frank A, Gochfeld M, et al. The case for global ban on asbestos. Environ Health Perspect. 2010;118(7): 897-901.

5. Ross M, Nolan RP. History of asbestos discovery and use and asbestos-related disease in context with the occurrence of asbestos within ophiolite complexes. In: Dilek Y, Newcomb S, editors. Ophiolite concept and the evolution of geological thought. Boulder: Geological Society of America; 2003. p. 447-70.

6. Więcek E. Azbest-narażenie i skutki zdrowotne. Bezpieczeństwo Pracy. 2004;2:2-6 (in Polish).

7. Szeszenia-Dąbrowska N. Azbest. Ekspozycja zawodowa i środowiskowa. Skutki i profilaktyka. Łódź: Instytut Medycyny Pracy; 2004. (in Polish).

8. Mirick W, Forrister WB. Products for treating asbestos. Patent USA No 5258131. 1993.
9. Sugama T, Sabatini R, Petrakis L. Decomposition of chrysotile asbestos by fluorosulfonic acid. Ind Eng Chem Res. 1998;37: 79-88.

10. Vast P, Andries V, Martines MAU, Auffredic JP, et al. Treatment and destruction of inorganic fibers wastes like asbestos by sodium polyphosphate. Phosphorus Res Bull. 2004;15:68-82.

11. Turci S, Tomatis M, Mantegma S, Cravotto G, et al. The combination of oxalic acid with power ultrasound fully degrades chrystotile asbestos fibres. J Environ Monit. 2007;9:1064-6.

12. Yanagisawa K, Kozawa T, Onda A, Kanazawa M, et al. A novel decomposition technique of friable asbestos by $\mathrm{CHClF}_{2}$-decomposed acidic gas. J Hazard Mater. 2009;163:593-9.

13. Anastasiadou K, Axiotis D, Gidarakos E. Hydrothermal conversion of chrysotile asbestos using near supercritical conditions. J Hazard Mater. 2010;179:926-32.

14. Plescia P, Gizzi D, Benedetti S, Camilucci L, et al. Mechanochemical treatment to recycling asbestos-containing waste. Waste Manage. 2003;23:209-18.

15. Colangelo F, Cioffi R, Lavorgna M, Verdolotti L, et al. Treatment and recycling of asbestos-cement containing waste. J Hazard Mater. 2011;195:391-7.

16. Leonelli C, Veronesi P, Boccaccini DN, Rivasi MR, et al. Microwave thermal inertisation of asbestos containing waste and its recycling in traditional ceramics. J Hazard Mater. 2006;B135:149-55.

17. Dellisanti F, Rossi PL, Valdre G. Remediation of asbestos containing materials by Joule heating vitrification performed in a prepilot apparatus. Int J Miner Process. 2009;91:61-7.

18. Boccaccini DN, Leonelli C, Rivasi MR, Romagnoli M, et al. Recycling of microwave inertised asbestos containing waste in refractory materials. J Eur Ceram Soc. 2007;27:1855-8.

19. Kozawa T, Onda A, Yanagisawa K, Chiba O, et al. Thermal decomposition of chrysotile-containing wastes in a water vapor atmosphere. J Ceram Soc Jpn. 2010;118:1199-201.

20. Gualtieri A, Giacobbe C, Sardisco L, Saraceno M, et al. Recycling of the product of thermal inertization of cement-asbestos for various industrial application. Waste Manage. 2011;31:91-100.

21. Gualtieri A, Boccaletti M. Recycling of the product of thermal inertization of cement-asbestos for the production of concrete. Constr Build Mater. 2011;25:3561-9.

22. Brindley GW, Zussman J. A structural study of the thermal transformation of serpentine minerals to forsterite. Am Mineral. 1957;42:461-74.

23. Le Cilliers JJ, Freeman AG, Hodgson A, Taylor HFW. Crocidolite from the Koegas-Westerberg area, South Africa. Econ Geol. 1961;56:1421-37.

24. Martin CJ. The thermal decomposition of chrysotile. Mineral Mag. 1977;41:453-9.

25. MacKenzie KJD, Meinhold RH. Thermal reactions of chrysotile revisited: a ${ }^{29} \mathrm{Si}$ and ${ }^{25} \mathrm{Mg}$ MAS NMR study. Am Mineral. 1994;79:43-50.

26. Jeyaratnam M, West NG. A study of heat-degraded chrysotile, amosite and crocidolite by X-ray diffraction. Ann Occup Hyg. 1994;38:137-48.

27. Cattaneo A, Gualtieri AF, Artioli G. Kinetic study of the dehydroxylation of chrysotile asbestos with temperature by in situ XRPD. Phys Chem Miner. 2003;30:177-83.

28. Gualtieri AF, Levy D, Belluso E, Dapiaggi M. Kinetics of the decomposition of crocidolite asbestos: a preliminary real-time X-ray powder diffraction study. Mater Sci Forum. 2004;443-444:291-4.

29. Hashimoto S, Takeda H, Okuda A, Kambayashi A, et al. Detoxification of industrial asbestos waste by low-temperature heating in a vacuum. J Ceram Soc Jpn. 2008;116:242-6.

30. Malkov AA, Korytkova EN, Maslennikova TP, Shtykhova AM, et al. Effect of heat treatment on structural-chemical transformations in magnesium hydrosilicate $\left[\mathrm{Mg}_{3} \mathrm{Si}_{2} \mathrm{O}_{5}(\mathrm{OH})_{4}\right]$ nanotubes. Russ J Appl Chem. 2009;82(12):2079-86. 
31. Zaremba T, Krzạkała A, Piotrowski J, Garczorz D. Study on the thermal decomposition of chrysotile asbestos. J Therm Anal Calorim. 2010;101:479-85.

32. Kusiorowski R, Zaremba T, Piotrowski J, Adamek J. Thermal decomposition of different types of asbestos. J Therm Anal Calorim. 2012;109:693-704.

33. Dias CMR, Cincotto MA, Savastano H, John VM. Long-term aging of fiber-cement corrugated sheets-the effect of carbonation, leaching and acid rain. Cem Concr Compos. 2008;30: 255-65.

34. Gualtieri AF, Tartaglia A. Thermal decomposition of asbestos and recycling in traditional ceramics. J Eur Ceram Soc. 2000;20: 1409-18.

35. Gualtieri AF, Cavenati C, Zanatto I, Meloni M, et al. The transformation sequence of cement-asbestos slates up to $1200{ }^{\circ} \mathrm{C}$ and safe recycling of the reaction product in stoneware tile mixtures. J Hazard Mater. 2008;152:563-70.

36. Gualtieri AF, Gualtieri ML, Tonelli M. In situ ESEM study of the thermal decomposition of chrysotile asbestos in view of safe recycling of the transformation product. J Hazard Mater. 2008; 156:260-6.

37. Dellisanti F, Minguzzi V, Morandi N. Experimental results from thermal treatment of asbestos containing materials. GeoActa. 2001-2002;1:61-70.

38. Bădănoiu A, Paceagiu J, Voicu G. Hydration and hardening processes of Portland cements obtained from clinkers mineralized with fluoride and oxides. J Therm Anal Calorim. 2011;103: 879-88.

39. Perez-Rodriguez JL, Duran A, Perez-Marqueda LA. Thermal study of unaltered and altered dolomitic rock samples from ancient monuments. J Therm Anal Calorim. 2011;104:467-74.
40. Hashem FS, Amin MS, El-Gamal SMA. Improvement of acid resistance of Portland cement pastes using rice husk ash and cement klin dust as additives. J Therm Anal Calorim. 2013;111: 1391-8.

41. Stepkowska ET, Blanes JM, Real C, Perez-Rodriguez JL. Hydration products in two aged cement pastes. Thermochim Acta. 2004;420:79-87.

42. Pacewska B, Wilińska I, Nowacka M. Studies on the influence of different Ely ashes and Portland cement on early hydration of calcium aluminate cement. J Therm Anal Calorim. 2011;106:859-68.

43. Stepkowska ET, Blanes JM, Franco F, Real C, Perez-Rodriguez JL. Phase transformation on heating of an aged cement paste. J Therm Anal Calorim. 2005;82:731-9.

44. Gerasimov MV, Dikov YP, Yakovlev OI, Wlotzka F. Hightemperature vaporization of gypsum and anhydrite: experimental results. In: Abstracts of the 25th Lunar and Planetary Science Conference. Houston: Lunar and Planetary Institute NASA; 1994. p. 413-4.

45. Pisarek B, Pawlak M. Selection of the temperature of casting the bronzes to plaster moulds. Arch Foundry Eng. 2009;9(4):203-8.

46. Ingo GM, Chiozzini G, Faccenda V, Bemporad E, Riccucci C. Thermal and microchemical characterizations of $\mathrm{CaSO}_{4}-\mathrm{SiO}_{2}$ investment materials for casting jewellery alloys. Thermochim Acta. 1998;321:175-83.

47. O'Gorman JV, Walker PL. Thermal behavior of mineral fractions separated from selected American coals. Fuel. 1973;52:71-9.

48. Luk WK, Darvell BW. Effect of burnout temperature on strength of gypsum-bonded investments. Dent Mater. 2003;19:552-7.

49. Piriou B, McMillan P. The high-frequency vibrational spectra of vitreous and crystalline orthosilicates. Am Mineral. 1983;68: 426-43. 